Between Dependency and Autonomy 
Science, Technology and the Changing World Order edited by Ernst B. Haas and John Gerard Ruggie

Scientists and World Order:

The Uses of Technical Knowledge

in International Organizations,

by Ernst B. Haas, Mary Pat Williams and Don Babai

Pollution, Politics, and International Law:

Tankers at Sea,

by R. Michael M'Gonigle and Mark W. Zacher

Plutonium, Power, and Politics:

International Arrangements for the Disposition of

Spent Nuclear Fuel,

by Gene I. Rochlin

Between Dependency and Autonomy:

India's Experience with the International Computer Industry, by Joseph M. Grieco 


\section{Between Dependency and Autonomy}

India's Experience

with the International

Computer Industry

Joseph M. Grieco

University of California Press Berkeley $\bullet$ Los Angeles $•$ London 
University of California Press

Berkeley and Los Angeles, California

University of California Press, Ltd.

London, England

(C) 1984 by

The Regents of the University of California

Printed in the United States of America

$\begin{array}{lllllllll}1 & 2 & 3 & 4 & 5 & 6 & 7 & 8 & 9\end{array}$

\section{Library of Congress Cataloging in Publication Data}

\section{Grieco, Joseph M.}

Between dependency and autonomy.

(Science, technology, and the changing world order)

Bibliography: $\mathrm{p}$.

Includes index.

1. Computer industry-India. 2. International business enterprisesIndia. I. Title. II. Series.

HD9696.C63I44 $1983 \quad 338.8^{\prime} 87 \quad 83-4866$

ISBN 0-520-04819-9 
To my parents,

Mauro and Mary Grieco 
